\title{
BIRDS AND FORESTS
}

T HE Council of the British Trust for Ornithology has recently taken the initiative in promoting discussions with other bodies interested in economic aspects of ornithology. The second of its series of joint conferences was hold at Northerwood House, Lyndhurst, Hampshire, during Oetober 30-November 1. The Forestry Commission was the Trust's partner in organizing the conference, and the subject was "Birds and Forests".

In opening the conference, Mr. E. M. Nicholson (Nature Conservancy) reviewed the relations between birds and forestry. He pointed out that remarkably little experimental work had so far been done in Britain to assess the part played by birds in the forest economy; the work of the Edward Grey Institute of Field Ornithology on tits and other birds in the Breckland and the Forest of Dean, and of H. N. Southern, of the Bureau of Animal Population, on the tawny owl in Wytham Wood, were examples of what could be done. He called for a new look at the problems of forest ornithology as a whole.

Mr. T. R. Peace (Forestry Commission) referred to the recent shift of emphasis from the idea of creating a strategic reserve of timber to that of economic forestry. This meant turning away from the natural forest towards a greater degree of deliberate tree farming. The Commission, as its creation of National Forest Parks has shown, was always prepared to pay attention to amenity; but economic considerations do not permit forests to be designed primarily for the encouragement of wild life. The Forestry Commission had not so far undertaken any research on problems of forest ornithology because it did not believe a case had yet been made out for birds being sufficiently beneficial to woodlands under British conditions to justify this.

In the subsequent discussion the point was brought out that the forester was faced with a choice between the small but continuing expense of providing and maintaining nest-boxes in order to increase the population of pest-predator birds and the much greater, but only very occasional, expense of attacking an infestation with sprays.

Mr. A. R. Mitchell (Forestry Commission) described the impact of forestry practice on bird life in woodlands. Wood-larks, for example, found forest nurseries a suitable habitat. On the other hand, the first thinning of a new plantation removed the forked and crooked trees in which birds liked to nest.

Dr. J. A. Gibb (Animal Ecology Section, Department of Scientific and Industrial Research, New Zealand ; formerly of the Edward Grey Institute of Field Ornithology, Oxford) sent a paper describing the work of the Breckland Research Unit of the Edward Grey Institute with special reference to populations of insectivorous birds and their food supply in pine plantations. The Unit was able to demonstrate that the density of tits and goldcrests in the Breckland pine plantations (mainly 20-30 years old) in winter varied closely with their stock of food. In severe winters, the tits and goldcrests might be actually consuming 40 per cent of the total amount of insect food available for them, and very much larger proportions of the available supplies of their favourite foods. Though this did not by itself prove that the birds' numbers were being controlled in a density-dependent way by food shortage, it did prove the existence of the indispensable condition needed for this method of control to operate.

The result of the Breckland work was to suggest that the provision of nest-boxes, though increasing the local density of birds in the breeding season. could not enable a greater number of tits to survive the crucial winter season in any particular forest. It might indeed be more to the point to increase the stock of winter food available for the birds by planting suitable trees and shrubs on the forest margins to diversify the supply; for example, spruce and beech would provide autumn stocks of food for coal tits, which they could store for use in the winter (pines shed their seeds in spring).

As regards the impact of birds on insect populations, the Breckland researches showed that bird predation accounted for a substantial proportion of insect stocks, so that birds are a force to be reckoned with in forest economics.

Dr. Herbert Bruns (Staatliche Vogelschutzwarte, Hamburg) described various aspects of forest research on economic ornithology in Germany. Food studies showed that, on the whole, insect-eating birds fed chiefly on pest-insects, sometimes in large quantities. This did not, however, necessarily prove that they were important controls on these insects. However, there were several convincing examples in Germany where it could be proved that birds had actively controlled insect pests. In one pine forest in Baden it had been shown that insect infestation was much worse in nearly birdless monocultural plantations than in bird-rich woods nearby. When more nestboxes were brought into the wood, the infestation was reduced.

Summing up, Dr. Bruns said that birds were not a panacea for all forest ills; but an important link in the natural chain of factors making for a healthy forest. Methods of sylviculture were most important, and it must be borne in mind that most German forests were much more mature than the average British forest. Much of the different British experience might be due to the immaturity of many British forests. The critical age for pest-devastation came at $60-70$ years.

Mr. R. K. Murton (Ministry of Agriculture) discussed the control of wood-pigeons, which might be a serious forest pest, especially to the leading shoots of Sitka spruce and other species. In East Anglia at least the Forestry Commission could be absolved from generating a high population of wood-pigeons, for their plantations were too extensive. Dense nesting of wood-pigeons only occurs in a fringe about 100 yards deep around the edges of large blocks of woodland, since the birds are unwilling to nest very far from their feeding-grounds. Wood-pigeons therefore prefer to breed in hedgerows, shelter-belts and the small spinneys planted as shelter for game. The game preserver indeed was largely responsible for the existence of the plague of wood-pigeons in East Anglia, for in addition to providing their nesting places, he prevented any control measures until February, after the shooting season, when much damage had already been done to the crops of farmers and foresters. Moreover, it was the keeper who killed off the two principal predators of the wood-pigeon, 
the jay and the magpie, which are responsible for 80 per cent of the losses of wood-pigeons' eggs.

Dr. Bruce Campbell (British Trust for Ornithology) discussed population problems in a typical insecteating forest bird, the pied flycatcher, illustrated by the ringing and nest-box experiments he was undertaking in the Forest of Dean.

Mr. W. A. Cadman (Forestry Commission) described the progression of wild life at various stages in the development of forests. He said that the pine marten had increased in some Welsh forests.

Mr. Nigel Gray (Imperial Chemical Industries Game Research Station) discussed the relations between game preservation and forestry. He said that good forestry made for good game habitat; but it was essential to have a reasonable mixture of tree species. If the Forestry Commission were to appoint game advisers, it would succeed in greatly boosting private forestry, by showing owners how it could be combined with game preservation.

Dr. I. D. Pennie (British Trust for Ornithology) spoke about the capercaillie and its effects on woodlands. Foresters claimed that in autumn and winter the capercaillie ate almost exclusively the shoots and buds of conifers; but in fact it seemed much to prefer the shoots of transplanted trees in nurseries and plantations to those of naturally regenerating trees. It was thus the shift in forestry practice, from the natural woodland to the artificial plantation, that had transformed this normal member of the woodland avifauna of northern Europe into a forest pest in parts of Scotland.

There were two field excursions during the conference, one under Mr. B. Gale, with a forestry angle, and one under Mr. Edwin Cohen, mainly for birdwatchers.
R. S. R. Fitter

\section{OBITUARIES}

\section{Mr. E. Price Evans}

Mr. Evan Price Evans died on April 27, 1959, at his home in Eastbourne, aged seventy-seven. He will be remembered for the part he played in introducing the teaching of plant ecology into schools ; it is probably quite largely due to him that at least in some schools ecological teaching on scientific lines has taken the place of mere 'Nature study'.

Price Evans was a Welsh-speaking Welshman, born at Corris in Merioneth on January 19, 1882. Educated in his native village and at Towyn County School, he entered the University College of North Wales, Bangor, in 1900 and was trained to be a teacher. There he attended the botanical lectures of Prof. Reginald Phillips and Dr. (later Prof.) J. Lloyd Williams. His first appointment was at his own school at Towyn, under the headmastership of a notable chemist, Thomas Jones.

At Towyn he had already experimented with teaching field botany even to quite junior forms, and he later developed this teaching when holding a post at Ryhope, Co. Durham. In his youth, however, he was better known as a footballer than as a scientist and at one time played for Wales in the amateur internationals. From Ryhope he went to Warrington, where he became headmaster of the Grammar School.

At Ryhope from 1913 onwards he began teaching ecology and vegetation mapping to his classes, and his efforts in this direction led him to correspond with the late Sir Arthur Tansley, who was then at Cambridge. Tansley encouraged him to publish an account of his teaching methods in the School Science Review, and later they wrote in collaboration "Plant Ecology and the School" (1946).

Price Evans was a keen student of vegetation on his own account, especially that of his native mountains, which he knew very intimately. He contributed several papers to the Journal of Ecology, of which one dealing with Cader Idris is still the only published account of the vegetation of a geologically and botanically very interesting area and is often quoted. He was an accurate observer and kept notes method. ically; his unpublished note-books are full of valuable observations on the plants and plant com- munities of North Wales. The University of Wales recognized his work by awarding him the honorary degree of M.Sc. in 1933.

During and after the Second World War, Price Evans was a keen supporter of Nature conservation. and he was an active member of the Nature Conservancy's Committee for Wales from its inception until shortly before his death. He had a vigorous and friendly personality and will be much missed.

P. W. RICHARDS

\section{Dr. Z. K. A. Moszynski}

Dr. Z. K. A. Moszynskr, a principal scientific officer of the British Coke Research Association, died at his home in Chesterfield, Derbyshire, on February 13. Zbigniew Konrad Antoni Moszynski was born at Lwow, Poland, on December 16, 1907, and studied in the Department of Chemical Engineering, University of Lwow (1927-34), where he took his diploma (Dipl. Ing.). During 1934-35 he worked in the Laboratory of Potassium Salts, University of Lwow. During 1935-39 he was deputy inspector for civil defence of industry, Polish Ministry of Defence, in the County of Lwow.

In August 1939 he was mobilized and served in the Polish-German campaign, escaping to Hungary, where he was interned. For five months he was assistant to the professor of agricultural chemistry, University of Magyarovar, but in March 1940 he joined the Polish forces in France, being evacuated to England. On behalf of the Polish General Staff he carried out research work in the Mining Department, University of Birmingham, between 1944 and 1945 on the use of carbonized peat/coal blends for mobile gas generators. During 1946-47 he continued and extended this work on the production of reactive carbonized fuels in the Fuel Department, University of Leeds, and obtained the degree of doctor of philosophy.

In September 1947 he was demobilized and in the same year became a British subject. He joined the staff of the British Coke Research Association, at the Midland Coke Research Station, where he was in charge of personnel and acted as secretary of a 